\title{
Inventor dispute over rapid-uptake insulin
}

The Federal Circuit has overturned an Indiana district court's judgement in an inventorship dispute between Eli Lilly and Aradigm Corp over a patent covering a method of aerosolized rapid-uptake delivery of insulin. Lilly had successfully sued Aradigm in seeking to have two of its scientists recognized as joint inventors on Aradigm's patent (US 5,888,477), although the district court ordered the addition of only one of the scientists, Richard DiMarchi, as inventor. However, the Federal Circuit ruled that Lilly was unable to prove that its scientists were co-inventors on the Aradigm patent.

DiMarchi is the inventor of Lilly's insulin analogue Lispro (marketed as Humalog), covered by patent US 5,514,646. Insulin molecules tend to form stable hexamers in solution, leading to a delay between injection or inhalation and therapeutic effect. Slight structural modifications in Lispro result in less selfassociation and more rapid therapeutic onset. The ' 477 patent issued to Aradigm covers the use of monomeric insulin as a means for improving the bioavailability of inhaled insulin.
Lilly claimed that Aradigm improperly appropriated information about the advantages of pulmonary delivery of Lispro from Lilly and incorrectly claimed the invention in the ' 477 patent exclusively as their own. In 1995 and 1996, the two companies held four meetings to discuss a possible collaboration that would take advantage of the expertise of both companies. Lilly insists that its scientists showed Aradigm the specific advantages expected from using Lispro instead of regular insulin in an aerosol device.

The Federal court agreed with Aradigm that Lilly did not present substantial evidence for the jury to determine that its scientists communicated the subject matter to Aradigm to a clear and convincing standard. No Lilly scientists testified directly that they discussed with Aradigm the use of Lispro for aerosolized delivery. The district court therefore had improperly relied on circumstantial evidence.

Eli Lilly \& Co. versus Aradigm Corp.: www.fedcir.gov/opinions/03-1336

\section{OncoMouse patent restricted in Europe again}

The 'Harvard OncoMouse' patent (EP $0,169,672$ ) has been further restricted, after several organizations appealed a March 2003 European Patent Office (EPO) decision to allow the patent to apply to all rodents. The OncoMouse is a transgenic mouse that contains the Myc oncogene, and so has a predisposition to develop cancer.

In 1985, its inventors - Timothy Steward and Philip Leder of Harvard University applied for a European patent entitled 'Method for producing transgenic animals'. The patent was granted in May 1992 for non-human mammalian animals for the eleven member states of the European Patent Organisation. In 1992 and 1993, seventeen oppositions against the patent were filed, which led to the decision in November 2001 to confine the patent to transgenic rodents. The EPO limited the patent to rodents because it felt that it was impossible to assume that the balance between benefit to society and suffering to the mouse could be automatically extended to all types of animal.

The appeals lodged in March 2003 by six of the original opponents, including the British Union for the Abolition of Vivisection, claimed that the patent did not meet the requirements of novelty and inventive step, and was contrary to public order and morality. The Technical Board of Appeal, the final judicial body of the EPO, heard the appeals and decided to restrict the patent further to 'transgenic mice'. The EPO has yet to publish the full reasons for the decision, which could have a significant effect on other patents and patent applications involving animals.

Although the patent has been granted in the US and Japan, in February 2003 the Canadian Supreme Court ruled by a five-to-four decision that the transgenic mouse is not an invention and cannot be patented in Canada.

Patent EP 0,169,672: http://v3.espacenet.com/textdoc? $\mathrm{DB}=E P O D O C \& I D X=E P 0169672 \& C Y=e p \& L G=e n$

\section{Filing an ANDA alone cannot be wilful infringement}

The US Federal Circuit Appeals Court has overturned a district court's award of attorney fees to GlaxoSmithKline (GSK) in their case against Apotex for wilful infringement of their patents, because Apotex's filing of an Abbreviated New Drug Application (ANDA) does not alone constitute such infringement. However, the Appellate Court upheld the ruling that Apotex's ANDA infringes two of GSK's patents (US 4,562,181 and US $4,820,833$ ) for cephalosporin antibiotics.

Under the Hatch-Waxman act, patentees must list patents related to their approved drug in the FDA's Approved Drug Products publication (the 'Orange book'). When a manufacturer files an ANDA for a generic drug, it must consult the Orange book and certify that there is no listed patent information for the proposed drug, that the listed patents have expired or will do so before any generic product is marketed, or that the patents listed are invalid or will not be infringed by the generic drug (also known as 'paragraph IV certification'). Because GSK's cephalosporin antibiotic cefuroxime (Ceftin) was approved before the Hatch-Waxman Act came into effect in 1984, GSK was exempt from listing the Ceftin-related patents in the Orange Book, and therefore ANDA applicants attempting to market generics of such drugs are not required to file a certification.

The Federal Circuit agreed with Apotex's argument that the mere filing of an ANDA and in particular one without a paragraph IV certification of invalidity and/or noninfringement - cannot constitute grounds for a wilful infringement finding. They noted that, in any case, filing an ANDA is a highly artificial act of infringement and gives rise only to a limited set of legal consequences. Judge Dyk agreed that Apotex's ANDA had infringed the ' 181 and ' 883 patents, but dissented on jurisdictional grounds to the infringement ruling because no damages were being sought and the patents have expired, making the whole issue moot.

Glaxo Group, Ltd. and SmithKline Beecham Corp. versus Apotex, Inc.: www.fedcir.gov/opinions/03-1575

PATENT ADVISORS

Leslie Meyer-Leon: IP Legal Strategies Group, Cape Cod, MA, USA Philip Webber: Frank B. Dehn \& Co. London, UK 